\title{
THE SIGNIFICANGE OF THE RIGHT HAND AND THE RIGHT SIDE IN VEDIC RITUAL
}

\section{Professor Dr. J. Gonda}

Utrecht

In an important publication which, being written in Dutch, did not perhaps attract the attention it deserves $W$. Caland at the time (1898) described and explained a number of ancient Indian ritual customs and directions characterized by various forms of orientation. Among these were the use of the right or the left hand in performing rites, and the so-called pradaksina, the circumambulation from left to right of a person or object (in rebus faustis) and its counterpart the prasavyam circumambulation (in rebus infaustis). ${ }^{1}$ Since orientation in the largest sense of the term is one of the striking features of Vedic and post-Vedic ritual and the texts evidencing the importance attached to the pertinent orientations are very numerous, it is not strange to say that the author should have left some practices and ritualistic motivations out of account. Nor is it surprising that some scholars who after him dealt with the ritual significance of the right and left sides and, especially, of circumambulations were inclined to call part of his conclusions in doubt. Thus, S. Eitrem (1915, p. 30), followed by $O$. Weinreich (I92 I, p. I33), ventured the opinion that a circumambulation from left to right was not, as was assumed by Caland, prescribed in rebus faustis because it reproduced the daily movement of the sun, but because the right side of a person is stronger, and hence 'better' than his left side. ${ }^{2}$ The latter opinion was also shared by R. Hertz (1909; I 928 ; 1960) who, however, ascribed the special preference for the right hand and the inferiority of the left side in general, not to physiological but to cultural factors: dividing the cosmos into two parts, a male and 'holy' or auspicious on the one hand, and a female and 'profane' or inauspicious one on the other, and homologizing his own microcosmos with the macrocosmos, 'primitive' man co-ordinated the former ideas with the right, the latter with the left side. In view of the almost general predominance and respectability of the right hand (Wile, 1934) the Dutch anthropologist Alb. C. Kruyt was, in an article on the preference for the right or the left side in religious customs of the peoples of Celebes (I94I, p. 339 f.), inclined to follow him. ${ }^{3}$

Leaving, in this article, circumambulations ${ }^{4}$ (Caland, $1898, \mathrm{pp} .13 \mathrm{ff}$.), the sacred cord worn over the left shoulder (o.c., pp. $8 \mathrm{f}$.), and other customs on which Caland focused his readers' attention, out of account, ${ }^{5}$ 
I limit myself to the comment that I have grave doubts about any onesided explanation which pretends to be more or less exclusive. Moreover, I hardly see the good of engaging in discussions of what was in hoary prehistoric antiquity the first or 'original' inducement to prefer, in many situations, the right side to the left. For the same reason, I shall take for granted that, also in ancient India, righthandedness was normal, without presuming to give an opinion on the vexed question of the origin of this manual preference. I also readily admit that the mind of 'semi-primitive' man, very conversant with lines of thought based on the principle of complementary duality, was deeply impressed by the symmetry of the human body and the opposition of left and right in general. In view of the widespread tendency to turn, in rites etc., towards the East, a close association of the right side with what is light and favourable is not surprising.

It will rather be my purpose to collect and, if possible, to explain some of those text-places which either escaped the observation of my predecessors or are worth noticing once again. In so doing I shall not aim at completeness. What will strike us is, first, that not infrequently the pertinent texts admit of more than one single or one-sided explanation; that things are often more varied and complicated than scholars were prepared to take for granted, and in the second place that in many cases there is no evidence of any connection with the sun. The opportunity will, moreover, present itself to draw attention to some views of the ancient ritualists themselves regarding the customs under examination and to test some hypotheses in relation to the preference for the right side as far as the Vedic material is concerned.

There are indeed more pertinent places in Vedic literature than those discussed by Caland and some of these may be of some interest in view of the question as to why, in ancient Indian antiquity, the right-or, in particular cases, the left - hand was used or, more generally, as to why the right side was so often preferred. It is especially the authors of the brāhmanas who, discussing the rituals in minute detail, make not only mention of numerous instances of this preference, but sometimes furnish us also with a motivation of a relevant ritual direction. ${ }^{6}$

In contradistinction to those languages in which van links naar rechts (Dutch), or neither to the left hand nor to the right are the usual or even fixed expressions, Vedic decidedly prefers to begin, for instance in enumerations, with the right. Thus in an enumeration of the main directions the right and the front sides have priority: 'I do not distinguish right or left, before or behind' ( $R V .2,27$, I I T TS. 2, I, I I, 5). Complicated ritual actions are performed in such a way that they begin on the right and end on the left side. When a sacrificial bed is sprinkled the order of the pertinent acts is: the 'navel' (centre), the right 'shoulder', the left 'buttock', the right 'buttock', the left 'shoulder', the centre (MSS. I, 7, 3, 31; similarly, 6, I, $8,5)$. Thus the Vaikhanasas prescribe (VaikhSmS. I, 2) that the one who ritually sips water should approach a river, face the east or the north, and wash his hands and feet, the right ones first. In detailed accounts of parts 
of a body the authors make mention of the right ear, etc. before the left (e.g. $A V .{ }_{15}, 8,3 ; S B .7,1,2,13 ; A i B .7,1$ ); the right eye-which at $A V .{ }_{15} 5,8,2$ is moreover identified with the sun-before the left; the right side before the left $(M S .3,15,5)$. Similarly, in an enumeration of the various parts of the sacrificial horse which are assigned to a host of deities, it reads: 'The right flank belong to Heaven and Earth, the left to the Viśve Devās' (VS. 25, 5). The right side takes also precedence in passages such as $S B$. I I, 5, 2, I ff., relating that Prajāpati fashioned his own body: the first limb which came into existence was his right arm, then his right leg, next his mouth, chest, abdomen etc., finally his left leg and his left arm. A man who lies on the earth may turn himself about 'on his right or left side' ( $A V$. 12, I, 34). In various ritual directions and explanations also the right side is mentioned before the left (see e.g., TS. 5, 3, I, 5; MS. I, 6, 6: 95, I 7; I, 8, 5: 121, 18;KS. 21, 7: 45, I $5 ; A V P .2,85,3 ; 7,15,1 ; S B .3,5,2,6 ; 8,4,4,1 ; 9,4,4,13 ; 12$, I, 4,$2 ; A i B .7,1,2 ; G B .1,3,14 ; 18 ; 1,5,3 ; A p S S .6,28,7 ; 15,7,3$; 16, 19, 7; VaikhSmS. 5, 1). In mythology it is not otherwise: Indra's right and left horse should be put to the chariot (RV. $1,82,5)$. The god Viṣnu is implored to fill his hands with abundant wealth and to bestow this from the right and from the left (VS. 5, 19); that is, the commentaries explain, with both hands. One mutters 'her names with the gods' in the right ear of the sāhasri cow which is in reality $V \bar{a} c$, i.e. Speech $(S B .4,5,8,10)$. Exceptions are few in number: the poet of $R V .8,24,5$, addressing Indra, states (probably for rythmical reasons) that neither thwarting influences nor hindrances can keep back the god's left and right hands.

The priority taken by the right side to the left, and by the front side (East) to the back (West), may be illustrated by a series of mantras intended to counteract the effects of portents coming from francoline partridges (Kausika-Sütra 46, 54;AVP. 20, 46, 7-10; RVKh. 2, 2, I): 'O partridge, utter a cry to us while moving to (standing on) the right; cry auspiciously from the right (southern) side, from the left (northern) side, from the front side (the East), from the back (West) . . . ${ }^{7}$

Now this precedence of the right side is, indeed, sometimes brought into connection with the revolution of the sun. ${ }^{8}$ In making a fire-place of the form of a bird, first the 'body' is produced, then the 'right wing', then the 'tail', then the 'left (wing)': 'that is in the rightward way, for this is (the way) with the gods, and thus, indeed, yonder sun moves along these worlds from left (uttara) to right' $(S B .8,7,2,13$; cf. 8, 7, 3, 5; $9,1,2,29) .9$

There can be no doubt whatever that Vedic man was convinced, or was aware, of the greater 'strength' of the right hand, arm or side. The question as to whether this fact is due to physiological factors or must rather be ascribed to an agelong training of that hand under the influence of social or religious motives (Hertz, I909: pp. $554 \mathrm{ff}$.) did not, as far as we are able to see, arrest his attention. ${ }^{10}$ The right side is explicitly said 
to be more powerful (more possessed of manly power or virility (viryavattara): $M S .3,2$, 10: 30,$17 ; P B .5,1,13)$. This expression (viryavat), deriving from virya 'manliness, energy, manly vigour, virility, strength, valour' - from vīra 'a (brave, eminent, heroic) man'-was, as we shall see, very usual in this connection, evidencing the intimate relation, in the minds of Vedic men, between the stronger right side and manliness. The close association of right with male and left with female has, for instance, also been recorded from various parts of the African continent, where the right hand is often called 'the male hand' (Wieschhoff, 1938: pp. $202 \mathrm{ff}$.), the left being, in 'lateral symbolism' associated with women, feminine tasks, subjects, bad omens. ${ }^{11}$

This correlation between the right side and strength exists also in the case of animals. 'He puts these animals which are the strongest on the right side: he thus makes the right side of an animal the stronger; whence the right side of an animal is the stronger' $(S B .8,2,4,19)$. The right side may also be made stronger by placing there something that is larger $(S B .8,6,2,12):$ in the opinion of the ritualists to whom we owe these texts the greater strength of the right side could as a matter of course be preserved or brought about by ritual methods. The text-place mentioned last, belonging to a long treatise on the construction of the great sacred fire-place, deals with the placing of definite bricks which represent the principal Vedic metres: if one places a large 'metre' on the right side one 'makes the right side of the animal the stronger, and hence the right side of an animal is the stronger'.

A sacrificial implement is said to be Indra's right arm (VS. I, 24; $K S$. 1, 9: 4, ro etc.), the commentator Uvata observing that this is 'the strongest' (of all tools). This explains why an enclosing-stick placed, for safety, on the south side of the sacrificial fire is likewise identified with the right arm of the same god (VS. 2, 3), and characterized as the fence of the sacrificer (TS. I, I, I 1, 2 and similarly, $K S$. 1, I I : 6, $4 ; S B$. 1, 3, 4, 3). A mythological explanation in the form of a reference to Prajäpati's creative activity is given in $K S .9, I 1: 112,18 \mathrm{f}$ : the creator god created the gods (deva) with his right, the anti-gods (asura) with his left hand; the former became strong (viryavant), the latter helpless (forsaken), and that is why the right side of a person is the stronger one. In a sacrificial rite referred to in $K S .29,8:$ i 76, i $5 \mathrm{ff}$. a correlation is assumed to exist between the comparatively strong gods and the South (or the right side) as the place where to sacrifice the victims and their comparatively weak colleagues and the North (or the left).

It has been surmised (Eitrem, I915, p. 30) that the natural inclination to turn clockwise is determined by physiological factors, e.g. the greater strength of the left leg. The Vedic ritualists seem to have been of the opinion that the centre of gravity of our body is in its right side and that therefore in turning round we are naturally inclined to move from left to right. In a description of the Full and New Moon rites, it reads (TS. I, $7,6,3$ ) '(while performing one of the obligatory acts) he turns to the right; verily he revolves round his own manly strength (viryam); therefore, the 
right side of a man is stronger (viryavattara); verily also he turns the turning of the sun'. This passage, which recurs at $T S .5,2,1,3 ; 5,2,5,4$; $K S$. 19, I : 13,13 , is interesting in that it connects man's turning to the right with the revolution of the great source of light. ${ }^{12}$ TS. $1,7,6,3$ commenting upon the ritual use of the formula 'I turn Indra's turn'which in $S \bar{A}$. 4,8 is used in a rite for preventing a person's children from dying before him-observes: 'Indra is yonder sun; verily he turns his turning. He turns to the right; verily he revolves round his own manly strength (viryam); therefore, the right side of a person is the stronger; verily also he turns the turning of the sun', and similarly $T S .5,2,1,3$, where, however, the turning round is said to take place also round one's own body. ${ }^{13}$ Indra's connection with the sun is indeed noteworthy (Keith, 1908: p. 25, n. 5) ${ }^{14}$ but it should not be forgotten that the idea of 'manly or heroic value' (viryam)is, in the Veda, often attributed to this god ( $R V$. , 57,$5 ; 80,7 ; 8 ; 2,13$, 11 etc.).

At $K S .24,4: 92,16$ the right side is said to be stronger (viryavattara) because with the right foot one follows in the steps of right feet of the cow with which the Soma is bought. ${ }^{15}$ At $M S .3,7,6: 83$, I ff. (cf. 3, 2, 10: $30,16 \mathrm{ff}$.) these facts-here formulated 'with the right side one goes out or forth after the right side'-are connected, not only with the habitual use of the right hand in eating, ${ }^{16}$ but also with the birds' following each other in turning to the right: one of those well-known instances of coordinating phenomena belonging to different provinces of nature. The vajra, i.e. the so-called thunderbolt weapon, is-like our swords etc.--said to be placed aside or to rest on the left and to be hurled away on the right (with the right hand): KS. $21,2: 3^{8,5}$ f.; KapS. 31, 17: 164, 14. Accordingly, while creating various creatures Prajāpati, to the accompaniment of a formula containing the name of Indra (the god who wields the vajra weapon), fastened the vajra on his right side, for victory (TS. 5, 3,6, 2).

It is therefore not surprising to read that with the right hand a weapon is taken $(R V .6,18,9)$ or wielded $(R V .6,22,9)$ and an enemy slain $(R V .8,2,32)$. The reference to Indra's left hand subduing even the mighty (RV. I, I0o, 9) may, I suppose, be taken to emphasize this great god's ambidexterity, a quality ascribed, in the Mahäbhärata, to his son Arjuna.

Obviously Indra's 'right-hand steed' was believed to be the strongest or swiftest of his horses, because among the formulas for the chariot-race which is a characteristic feature of the Vajjapeya rite the second horse to be yoked is (VS. 9, 8) addressed as follows: 'Steed, being yoked, become wind-swift; be through good fortune as Indra's right-hand steed'. When, according to the traditional interpretation, the god Pūsan is implored to lay from afar off (i.e. from the sphere of the gods) his right (fore-)arm round his worshippers, no doubt in order to protect them $(R V .6,54,10)$, it is probably again the strength and capability of this limb which are thrown into relief. The stanza has, however, been translated also as follows ${ }^{17}$ : 'Let Pūșan swing around his right hand (to point the direction) beyond', the god, as the solar pathfinder and tracker being asked to swing 
his right hand (which is generally employed for pointing) around to point to the lost or stolen property (Atkins, 194I: p. 64).

Is it because of the greater strength attributed to the right hand that in holding a stalk of grass it should take the bottom part while its top part is put in the left hand? $(S B .3,8,2,13)$. That the upper kindling wood should be taken up by the right hand, the lower kindling wood by the left (BhärParS. 213) is, however, only natural, but it is worth noticing that this minute detail is explicitly mentioned.

A curious opposition between both hands is mentioned in TS. 5, 3, 3, $3 \mathrm{ff}$ : because in laying down bricks for the fire-place to be built with a formula containing the word 'austerity' (tapas) 'the left hand is, of both hands, and in contradistinction to the other characterized as possessed of tapas'. This term (tapasvitara) is difficult of explanation; the commentary attributed to Sãyana suggests: 'because with that hand one cannot eat as with the other one', and if the adjective tapasvin here has the wellknown sense of 'wretched, poor, miserable', ${ }^{18}$ this explanation is in my opinion preferable to a modern translation 'the left hand has the greater fervour'. The text continues: 'with a formula containing the word "bringing together" or "making ready" (sambharana) one puts down in the north, therefore the left hand is sambhäryatara' (cf. also $K S$. 20, I3: 33, 20). The sense of this word is also uncertain; the author of the commentary thinks that it means: 'it is the best for bearing weights' which conflicts with its grammatical form; modern explanations are 'to be prepared or made useful', 'to be maintained', 'dependent'; I would propose: 'which (in contradistinction to the other) is more to be made ready' (because it is the weaker one). As is well known there exist stronger euphemistic expressions for the left side: in Sanskrit, vāma I 'lovely', 2 'left'; in

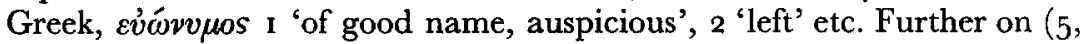
$3,3,5$ ) it is said that to the accompaniment of a formula referring to the sun one places pre-eminence in holiness or sacred knowledge (brahmavarcasa) in the South and that that is why the right side (here the word 'hand' is replaced by 'side') is in contradistinction to the opposite side characterized by this quality (similarly, at $T B .5,3,5,1$, and compare $M S .3,2$, 10: 30,$17 ; K S .8$, 12: 96,2 ; at $K S .20,13: 34,1$, it is the sun which gains brahmavarcasa from, or in, the South). This can hardly mean that it is 'the more resplendent', but rather 'that one which (in contradistinction to the other) is characterized as possessed of pre-eminence in holiness'. The occurrence of the term brahmavarcasa, which is usually a quality of living beings and especially an ideal accomplishment of a brahman (cf. $S B .1,9,3,16$ ), is remarkable. It may be clarified by a reference to $T B .7,3,9$, I stating that those who, in imitation of the gods, perform a definite rite become possessed of brahmavarcasa and eaters of food. ${ }^{19}$ The conclusion may be that in the above passage the right hand acquires the property indicated by the adjective 'possessed of brahmavarcasa' because this quality is often coupled with the idea of eating food, an act performed with that hand. One should not, however, suppress a reference to $S B .2,3$, I, 3 I where a prospect of having brahmavarcasa is held out to 
the man who knows that Agni, light and Sürya (the sun) are varcas 'lustre' and to TS. 2, I, 4, I ; 2, I, 8, 1; 2, 3, 2, 3 stating that for the one who desires brahmavarcasa one should, by means of definite sacrificial rites, have recourse to the sun, and recall that at $T S .5,3,3,5$ it is by reciting a formula dedicated to the Sun that one places brahmavarcasa on the South.

'On a souvent cherché dans le rôle différent des deux mains au combat, qui résulterait de la structure de l'organisme ou d'une sorte d'instinct, l'origine des représentations sur la droite et la gauche. Cette hypothèse, que réfutent des arguments péremptoires, prend pour la cause ce qui est un effet' (Hertz, I909: p. 574). However, normal right-handed combatants are more vulnerable or at least handicapped, if they are attacked from the right side. This consideration may have induced the poet of $R V .6$, $3^{2}, 5$ to use the adverb 'from the right': in this stanza Indra is described as causing the waters to flow, whilst overpowering the mighty one (in casu, the demon Vrtra) from the right side. It was no doubt the desire to avoid an attack on this side which led the poet of $R V$. 10, 83, $7(A V .4,32,7)$ to invite Manyu, Fury or Fighting Spirit, to assist him on that side so as to enable him to slay, together with this god, many enemies. A similar request occurs at $R V .8,100,2$ : 'If thou (Vișnu) wilt be my companion at my right side, we shall kill many opponents'. Indra, who is speaking here, does not offer the place of honour, nor address Viṣu as 'den vertrautesten Freund' (Geldner, I95 I : II, p. 428, n. I); he seeks cover. It may be recalled that formerly in warfare the cavalryman at the right of the line had duties of great responsibility.

Here I may interrupt myself to consider the meaning of the adjective daksina which is the usual expression for 'right'. The word also means 'south(ern), situated to the South etc.' and not infrequently both translations are possible. ${ }^{20}$ Moreover, it also denotes (though not, it is true, in Vedic literature proper) ideas such as 'dexterous, able, clever', and these meanings belong already in the earliest texts to the adjective daksa, which is etymologically related. Without entering into a discussion of the meanings of the related words in the other Indo-European languages, I would like to recall that the Greek $\delta \varepsilon \xi$ iós as well as the Latin dexter were likewise used to express the ideas of 'dexterous, skilful', so that basing ourselves on linguistic data we may regard the Vedic belief in the special ability or skilfulness of the right hand as inherited from the prehistoric period. ${ }^{21}$ That etymological considerations could play a part in the theories of the ritualists is, in view of the great importance attached by these authorities to etymologies as a means of penetrating into the reality behind the phenomena and of understanding the connections between these, perfectly intelligible (Gonda, 1955). One may for instance ascend a ladder from the south northwards ( $u d a k)$ rather than from the north southwards, because in the first way it goes 'upwards' (likewise indicated by the term udak: $S B .5,2$, I, 9).

The left side, often regarded as symbolizing weakness, is widely associated with women. ${ }^{22}$ In various present-day Indian ceremonies attended by men as well as women 'the performer takes his seat with the male 
members of the household on his right and the female members on his left' (Mills, 1922: p. 34; cf. p. 150). The bridegroom's or husband's place is on the right, his female partner sits down on his left (Mills, 1922: p. 15I ; 154). Even the garments of a married couple are in religious ceremonies placed in the same position (Mills, $1922:$ p. 152 ). ${ }^{23}$

In the Veda it is repeatedly stated ${ }^{24}$ that the wife-the weaker partnerlies on the left side of the man. That is why, the author of the SatapathaBrähmana argues, water is placed north (i.e. on the left) of the sacrificial fire, 'for water (being grammatically feminine) is female and fire is male: hence a copulation productive of offspring is thereby effected; in this way alone a regular copulation can take place' ( $1,1,1,20)$. For the same reason-'the male lies on the right side of the female'-a definite spade, the name of which is grammatically feminine, is placed on the north of the (male) a ahavaniya fire $(6,3,1,30)$. At $7,5,1,6$ the same motivation is furnished in connection with a similar ritual injunction. ${ }^{25}$

This position of the wife on the left side of her husband determines what shall be done with the ewe and the ram made of barley which in the Varunapraghāsa ceremonies (Hillebrandt, I897: pp. I 6 f.; Meyer, 1937: III, pp. $255 \mathrm{ff}$; Gonda, I960: p. 80) must be placed on two dishes of curds: the former is placed on the northern (left), the latter on the southern (right) dish (SB. 2, 5, 2, 1 7). However, in the course of the ritual one has to exchange these animals, because the male represents energy which should be bestowed on the nobility represented by Varuna who is in the north, and the female is without energy and should therefore accompany the Maruts in the south who represent the people which should be without energy (ibid. 36 ). ${ }^{26}$

Although in our eyes $J U B .1,53,3$ does not explain why it is the man who lies at the right side of his wife, ${ }^{27}$ this passage is worth quoting because it gives us some information on a 'system of correlations' including the right and left position. This universe was twofold in the beginning: the existent (cosmos) and the non-existent (chaos). The former is säman (song of praise), mind, exhalation, the latter $r c$ (recited praise), speech, inhalation. The regular seats of these powers (säman and $r c$ ) are mind and exhalation, speech and inhalation respectively. 'Therefore a man lies by a woman at the right side'. 'This $r c$ (female) desired intercourse with this säman (male) . . . The implication no doubt is this: as soon as the twofold universe tends to develop and differentiate, there come into being, or appear to exist, not only ritual and physiological concepts which are conceived of as male and female entities, but also the polarity of right and left with which they are co-ordinated. It is obviously regarded as selfevident that the 'existent' (cosmos), the säman, the first of the life-breaths and the man are co-ordinated with the right side. The text even goes so far as to suggest ${ }^{28}$ that the man occupies that place because of his implied identity with the male (masculine) säman etc.

I have my doubts about the correctness of Oertel's (1896: p. 234) explanation: 'the reason (of this position of the man) is very probably the desire for male offspring', because in a later work (Varāhamihira's 
Brhatsamhitā, VIth century A.D., $78(77), 24)$ a male foetus is believed to develop in the right side of the uterus, a female in the left. ${ }^{29}$ It would rather appear to me that this belief, of which there are many Greek parallels (Oertel, 1906 : pp. $189 \mathrm{f}$.), is-like the advice given to the husband to enter the nuptial bed with his right foot first, to his wife with her left foot first (Jolly, rgor : p. 5o) and the belief that a boy will be born if an expectant mother prefers food with masculine names, if her right eye becomes larger etc. (Jolly, 190I: p. 5I) and like the position of the husband at his wife's right-another instance of a co-ordination of the male sex and the right side. These places may shed light on the statement made in TS. 6, 2, 5, 5: 'The man who is consecrating himself is a foetus, the consecration-shed is the womb (in which he is). If he were to leave it, it would be as when a foetus falls from the womb. He must not leave it, to guard himself. He lies on the right side; that is the regular position of the sacrificer; verily he lies in his own abode (äyatane). He lies turned towards the fire; verily he lies turned towards the gods and the sacrifice'. The regular position (ajyatana) of the sacrificer coincides with the position of a male embryo in the womb.

It is characteristic of the brähmana texts that they are inclined to view this position of the man as secondary and to explain it as a corollary of a ritual practice. The man lies by the right side of his wife because definite sacred bricks are placed on the southern (right) side so as to be turned to the north $(K S .20,9: 28,12 ; \mathrm{cf} .20,6: 25,8)$. A similar ritual explanation is given of the fact that birds usually hover about along the right side $(K S .20,12: 32,10)$. In reading these passages, one should remember that for Vedic man the ritual was a means of organizing and controlling nature.

Interestingly enough, the conclusion was drawn that from the right side the seed is discharged, and that hence it is on the right thigh of the udgatar (one of the officiants) that fire must be churned $(P B .12,10,12)$. For the same reason a lump of clay must in constructing the great fireplace be taken from the right (south) to the left side of a hole because this hole is identified with Agni's womb $(S B .6,4,2,10)$. On a definite ritual occasion, the wives of those engaged in the rite have to pour water; thereby the participants emit semen, for semen is a fluid; the wives pour the water along their right thighs, because from the right side the semen is emitted (PB. 8, 7, 8 ff.).

Another no less interesting passage illustrates the tendency consciously to associate and co-ordinate different denotations of the right side: $\$ B$. 8, 4, 4, I I 'Some lay (definite bricks) down on the right (south) side, saying: "We thus place these signs of good fortune on the right side", whence he who has a mark on his right side is said to have good luck and on the left side in the case of a woman; for the woman has her position on the left side (of the man); therefore it is done thus'. The words 'and on the left in the case of a woman, for a woman has her position on the left side (of the man)' may be no more than a supplement in order to recall that the preceding statement is only applicable to men and that the difference in the case of a woman is determined by a reference to the fact that hers is 
the left side. ${ }^{30}$ The right side was indeed, in the case of male beings, auspicious, most probably because it was the 'male' side. If the flame of a (sacrificial) fire points to the right, this is a good omen; a royal sacrificer observing it will be victorious ( $A$ VPar. $70 \mathrm{C} 25,5) .^{31}$

A curious rite, mentioned $T S .3,4,8,3$ (see also $K S$. 37, 12: 93, I3; $B S S .14,17$ ), for the benefit of the prince whose realm is not in order consists in taking off the right wheel of one's chariot and offering in the box; 'so he puts in order his oblations, and the kingdom comes into order in accord with their coming into order'. The 'symbolism' of the wheel need not detain us; being circular it was a 'centre' containing power and the ruler who 'is situated in the wheel' (cakravartin) may be regarded as participating in its conquering efficacy - a wheel moves - and as occupying a central and dominant position (Gonda, 1966: pp. I23 f. and addenda). What interests us is that the rite should take place in the right wheel, no doubt because of the 'auspiciousness' of that side.

I need not dwell on the opposition between the left hand which, being infaustus, is used in 'witchcraft' and rites concerning the deceased and the right hand which, being characteristic of the gods (see e.g. $S B .2,4,2,1$; Caland, $1898:$ passim), is also, in a general sense, faustus. If the skin of a man's head is on the right side smooth (not hairy by nature where hair is expected) people speak of 'a congenital (auspicious) mark' (MS. I, 8, I : I 15,16 ). This conspicuousness of the right side is also apparent from the conviction that, if one were to pour one's oblations into the left (northern) fire, one would not get rid of evil, but when one offers into the right (southern) fire, one gets rid of it (KS. 12, I1: $173,14 \mathrm{ff}$.) ${ }^{32}$ In a text intended to drive away powers of evil or to discover, by means of a herb, sorcerers $(A V .4,20)$, the thousand-eyed god (according to the Indian commentary, Indra) is expected to 'set it on my right fore-arm' (rather than 'in my right hand'), the following words being 'with it I see everyone' (st. 5). 'It must be an amulet (cf. Kausika-Sütra, 28, 7) made of a plant called "Ever-flowering"', which obviously enables the man who wears it on his right arm to detect the evil-doers. If one wishes to put to sleep a woman and her attendants one must, while gazing at the right foreleg of her bed, pronounce the incantation $A V .4,5$ (Kausika-Sütra 36, 4). In these cases, it is essential to affect the right or stronger side in order to achieve the effect desired. In executing a charm against unlucky signs in a woman it is required to sprinkle her face, starting from the right lock of hair and to place husks and other refuse matter on the heel of her left foot. ${ }^{33}$ Should the 'evil' leave her, through the refuse, on that side? However, the mention of the right as well as the left side may also point to the desire to affect an object in its entirety. In a rite executed to drive off evil on every side a brick addressed as a 'eulogium' and representing creative vigour (ojas) and movable property is placed on the right, one representing lustre (varcas) and movable property on the left side $(\dot{S} B .8$, $5, \mathrm{I}, \mathrm{IO} ; \mathrm{I} \mathrm{I}$ ).

The Fathers and their region, the south, are not always unpropitious: at $S B .3,5,2,6$ the right (southern) side of the sacral fire-place is sprinkled 
with a formula which invokes the protection of the Fathers on the right. Since the decided preference for the left hand in the cult of the Fathers was amply discussed by Caland (1898), I need not dwell on this point. Suffice it to recall that the Toradjas of Celebes explain many customs relating to the cult of the deceased ancestors with a reference to their belief in the existence of a consistent opposition between the living and the dead, the latter behaving in a great variety of respects reversely (Kruyt, I94I: pp. $340 \mathrm{ff}$.). Hence also the conviction that in any contact or dealing with the deceased, one should, for the sake of safety, do like these, for instance use the left hand instead of the right. These considerations were not foreign to Vedic man. In connection with Caland's comment (1898: pp. $6 \mathrm{f}$.) upon the ritual usage to bend the right knee (see, e.g., $S B$. 12, 4, 4, 6) in worshipping the gods, the left knee in paying homage to the deceased ancestors, it may, for instance, be remembered that these classes of beings themselves were supposed to assume the same ceremonious postures $(\mathcal{S} B$. $2,4, \mathrm{I}, \mathrm{I}$ f.).$^{34}$ Remarkably enough, the poet of $R V .2,42$, who requests an ominous bird to cry on the right side of the house (st. 3), does not hesitate explicitly to invite it 'very auspiciously and uttering favourable sounds to cry out in the direction of the Fathers' (st. 2). These places find their explanation, on the one hand in the fact that the Fathers are far from being always dreaded and, on the other hand, in the prevalence of the auspicious nature of the right side, as long as there is no question of demoniac power and influences manifesting themselves from that side.

These considerations help us also to understand places such as the following: TS. 6, 6, 5, 4: if one should offer a victim to Varuna along the stream of the waters, this god would seize one's offspring. Therefore, one should offer it facing north, on the south side of the middle sacrificial post against the stream of the waters in order to prevent Varuna from seizing the offspring. If, with VS. 5, 19, which contains a blessing, one strikes in the prop of the southern oblation-holder, the sacrificer will, at the beginning of the sacrifice, win blessings (TS. 6, 2, 9, 3 f.).

The side of strength and auspiciousness is also widely regarded as that of benignity, allegiance, benediction, fraternal love (Jokes, $196 r: p .1338$ ). The Indian teacher, whilst initiating a pupil, laid his right hand on him to become 'pregnant' with him, so that on the third day the youth could be born as a brahmin $(S B .11,5,4,12)$. According to $A p D h S .1,2,5,21$ the pupil should salute his teacher by striking the latter's right foot with his right hand, but other authorities hold different views. ${ }^{35}$

However, from the fact that the right side takes precedence it does not necessarily follow that the left side is inauspicious or inferior. Sometimes it is rather considered to be of a secondary, complementary character ${ }^{36}$ what happens on the left side is regarded as necessarily and essentially subsequent to the events on the right side. Aitareya-Brähmana $8,27,8$ it reads: 'I wash my right foot; I place indriya (a variety of power) in this kingdom; I wash my left foot; I increase the indriya in this kingdom'.

Abstaining from an examination of those many places which attest to the great importance attached to the south-cf. $S G S$. I, 8, 5 'all kinds of 
rites are to be performed beginning south, ending north'; SSS. 2, I 1, I; 4, 6, I: acts pertaining to the sacrificer and those which fall to the share of the brahman priest are performed on the southern side (of the ground set apart for the sacred fires), no doubt for the sake of protection from ghostly and demoniac powers-I must, however, insert some remarks on those customs or ritual instructions which presuppose an identity of the right side and that cardinal point. ${ }^{37}$

As is well known the sacrifice should be protected, for instance by the person of the brahman priest, against the demons who live in the south. In particular contexts, it is moreover perfectly clear that the south must be 'fortified' because on that side an attack of the demons may always be impending. Places are indeed far from rare in which the gods are afraid of such an attack $(S B .3,5,3,15 ; 3,6,1,27)$, the inimical asuras, 'the mischievous fiends, try to smite the gods from that region' $(S B .9,2,3,2$; cf. 6) or 'wished to conquer the sacrifice' (MS. 3, 3, 7:40, $9 \mathrm{f}$.). That is also why once the gods while performing a sacrifice let Indra, the strongest of them, sit on the south side; 'We will then enter upon the sacrifice on the north side in a place free from danger and injury' $(S B .4,6,6$, I ff.). According to $A V .3,27,2$ Indra is the overlord of the southern direction and at $A V .12,3,24 ; A V P .17,38,4$ he is, together with his allies, the Maruts, invoked 'to defend on the south', whereas in the funeral hymn I8, 4, stanza 15 of the same corpus he is expressly invited to be 'on the right (on the south) the brahman priest' on the occasion of the cremation which is viewed as a sacrifice. See, e.g., also TS. 5, 5, 8, 2. Elsewhere, however, it is Savitar, the representative of the dynamic aspect of the sun, who is requested to protect the one who pronounces the formula on the south, and Indra on the north $(A V$. 19, 16, I and 19, 27, 14). At $A V$. 18, 3, 26 it is Dhătar, at $19,17,3$ and $19,18,3$ Soma with the Rudras, at $A V P .1,71,2$ Vāyu (Wind), at $A V P$. 16, 1 $3^{8,8}$ the Vasus, at $G B .2,6,6$ : 251, I $2 \mathrm{f}$. Varuna.

The southern soma-cart (i.e. the one on the right side) should be larger than the northern one $(S B .3,5,3,8)$. This rule has been brought into connection (Eggeling, I885: II, p. I27, n. 4) with the obligatory inclination of the shed in which these carts are placed towards the north, because that is the quarter of men ("were the sacrificial place to incline to the South, the quarter of the Fathers, the sacrifice would quickly go to yonder world', and the sacrificer would not live long: $S B .3,1,1,2)$. However, this is not necessarily the only motive.

Sometimes a ritual is performed at the right side because it should take place in the southern direction. One has to offer some ghee (clarified butter), first in the right wheel-track of the southern, and then in that of the northern soma-cart $(S B .3,5,3,13)$, in order to keep off the evil spirits from the south (ibid. I5). Elsewhere $(9,1,2,12)$ it is enjoined to throw 'one's pain, one's evil' southwards while standing at the right 'thigh' of the sacrificial bed with one's face to the east. A piece of gold is laid down in the right wheel-track, first of the southern, then of the northern soma-cart ( $S B .3,5,3,13$ f.; cf. $K S .25,8:$ I I4, 9; 25, 9: I I5, 9: 27, 5: 
144, 16). The cow for which the soma is bought has to approach on the right side of the front door of the hall $(3,2,4,15)$. At $M S .3,8,8: 106,8$ the right or southern oblation-holder is stated to be the front part of the oblation-holders.

In a description of the shed erected in the sacrificial enclosure, it reads 'In the world of the sacrificer are the southern coverings (of the roof), in that of his rival the northern; he makes the southern higher (with the result) that he makes the sacrificer higher than the man who does not sacrifice' (TS. 6, 2, 10, 7; cf. $K S .25$, 10: 119 , 13 ff.). ${ }^{38}$ Accordingly, the sacrificer is in a definite ritual situation to be on the right or southern, his rival on the left or northern side (KS. 25, 7: I I I, $20 \mathrm{f}$.), and the former side should be great, the latter deficient: an unmistakable instance of the association of the right: left opposition with social antagonism. Needless to say, the identity of the right side and the southern direction or quarter and that of the left and the northern direction is perfectly apparent from a large variety of other ritual directions: e.g., TS. $5,2,10,4$ " "this one on the right (south) . . .", (with these words he puts down) on the south"; $5,6,4,3$ 'that which the Creator god (Prajāpati) put down on the right side became the right side, that is the southern quarter'. $S B$. I 1, 2, 7, 33 etc. the right edge of the sacrificial bed is situated towards the south; I 4, 1, 2, 9. Definite complicated ritual acts begin in the south: 3, 5, 2, 10.

It is clear that the practical identity of right and southern and the different ideas which might be associated with the latter adjective might lead to conflicting situations which may occasionally give rise to some difference of opinion or are made the subject of a short discussion. The practice recommended by some authorities to anoint the sacrificer who is being consecrated on the right side of the fire-place, 'because it is from that side that food is served and they thus anoint him from the food-side', is rejected by the author of $S B$. 9, 3, 4, I I because that side, which is the south, belongs to the Fathers and that man would be liable quickly to go to their region if he was anointed in that way. ${ }^{39}$

The fundamental significance of the quarters of the universe and the tetradic organization of the same in Indian religious thought needs no comment (Gonda, 1970: p. 22r, s.v. disas). They were created by the Creator god as soon as he had, on the primeval waters, established the earth (Kap.S. 35, 3; TS. 5, 6, 4, 2 f.).

This narrative is also interesting in that it explicitly correlates the four sides of the Creator god (front, right side, etc.) with the four regions. In view of the comparatively speaking highly developed sense of orientation of the Indians it may allow the inference that man, regarding himself as 'four-sided', co-ordinated his 'sides' with the four cardinal points of the compass. ${ }^{40}$ It is, however, worth noticing that if mention must be made of the opposite quarters of the universe, the south preferably preceded the north $(S B .3,5,3,8 ; 21 f . ; 3,5,4,6$ etc.) also if both of them are, for instance, preceded by an indication of a position in the middle $(S B$. 1, 3, 4,3 ; cf. 3, 5, I, I ff. ; 8, 1, 3, 6; 8, 6, 1, 23; 13, 8, 3, 9). Otherwise, however, $S . B 7,5,2,14$ ff.; 14, 3, I, $21 ; 22$. 
Suppliants desirous of gifts grasp the right hand of a liberal person, in $R V .10,47,1$ of the god Indra, when they fear that he will go away before giving them something (thus Sãyana's explanation). ${ }^{41}$ The gifts are expected to be presented with the right hand $(8,8 \mathrm{I}, \mathrm{I} ; \mathrm{I}, \mathrm{O}, \mathrm{I} 80, \mathrm{r})$ and it is there that they are held in readiness ( $1,128,6) .{ }^{42} R V .8,81,6$, where Indra is requested to bring something to those speaking with his right hand and to grasp or seize it with the left reminds us of the ritual custom of the Hindus ${ }^{43}$ as well as their Vedic ancestors to hold the sacrificial gifts or consecrated material in their left hand-which is not used in worshipping the gods-before offering or applying them with their right hand. ${ }^{44}$ Vedic texts from which it appears that in sacrificing to the gods the sacrificial material is taken in the left hand but dispensed with the right are $S B$. 1, I, 3, 7, 'Having taken (the water with the ladle) in his left hand, he makes it spirt upwards with his right hand, and eulogizes and glorifies it'; or it is placed in the left hand and touched with the right: I, 2, 4, 5; I 4, I, 2, 8. It remains possible, of course, to give with the left and the right $(R V .5,36,4)$ or $(A V .7,26,8 ; V S .5,19$ etc. ') from the right and from the left', that is with both hands, or very liberally; compare also $T S$. I, 2, 13, 3; 1, 7, 13, 4 'Fill thy hands with many good things, give to us from right and from left'.

That the winning 'die' is in the right hand of the winner $\left(A V .7,5^{\circ}, 8\right)$ is intelligible, because he may be supposed to take it with that hand, but what is the meaning of the addition that "victory (with the "winning die", commentary) is placed in his left'? Is this addition due to the complementary character of the left side, to a sense of symmetry, to the tendency to polarity in expressing ideas of totality and completeness? Or has, what seems less probable, the left, in this connection, a special 'religious' meaning? It is the right hand with which an object is said to be taken $(R V$. I, Ioo, $9 ; 3,39,6$ ), the right hand with which for instance enjoyment is 'from the right side' to be 'milked' (extracted) out of the daksina $\bar{a}$, the sacrificial gift offered to the officiant (AVP. 7, 15, 9), which is extolled in this text.

That according to expectation it was customary practice to eat with one's right hand appears from $T S .5,3,3,3 ; 4 ; M S .3,2$, 10: 30, 17; $K S .20,12: 32,9 \cdot{ }^{45}$ It has been asserted (Hertz, 1909: p. 573) that the right hand was used because it was regarded as ritually 'pure': this may, to a certain extent, be true in the case of those who were used to reflect upon what they were doing, but for the others it may have been just another consequence of their righthandedness. The above places may be supplemented by $K S .20,12: 32,8 ; 20,13: 33$, 10; 1 I, I $: 37,7 ; K a p S .31$, 16: 164,2 informing us that 'food comes from the right'. It may be recalled that the sacrificial ladle is also 'borne to the right (of the fire)' (see, e.g., $R V . \mathrm{I}, \mathrm{I} 44, \mathrm{I} ; 3,6, \mathrm{r}$ ), and that already in Rgvedic times ritual acts were generally speaking performed 'from the right': at $R V .1,95,6$ ( $A V P .8,14,6)$ they (those whom it may concern) are said to anoint Agni with oblations, while beginning on the right side. ${ }^{48}$ Among the proper forms to be observed by the sacrificer is that he should, after 
washing his hands, place himself near the fire in order to worship it, from the right or south $(M S .1,4,5: 52,15)$. In directions relative to manual action the texts often make explicit mention of the right hand (e.g. ApSS. 2, $8,3)$. The sphya, a wooden sword-like implement used for stirring the offerings of boiled rice etc. is addressed as Indra's right arm (VS. I, 24 etc.). 'In front stands that cow by the sacrificer with her face towards the west, for from the right side they approach her . .' $(\hat{S B} B .9,1,2,15) .{ }^{47}$ $A V P .16,71,9$ is interesting in that it shows that eating, at least in the case of a sacrificial dish consisting of boiled rice which, after going to the 'heaven' of those who have earned religious merits awaited them there, was supposed to take place after the blessed had sat down from (on) the right side. The same situation recurs at $A V P$. I $7,39,3$ where the (female) divine beings are invited to settle together with the (male) gods to eat that dish on the right side.

In the Veda the higher rank of the right side is also apparent from ritual customs such as that described at $K S .23$, I : 73, I I ff.: in connection with the sacrifice being threefold the sacrificer while consecrating himself anoints his right eye twice, the left eye once; in connection with the fivefold sacrifice, his right eye three times, the other twice. It is 'to the right' that one invests one's self with the sacred thread $\left(M S\right.$. $\left.1,10,18: 15^{8}, 5\right) .^{48}$ The nivi, i.e. the tuck of the sacrificer's nether garment which in definite acts is to be pulled down $(S B .2,4,2,24)$, is sacred to the Fathers $(S B .2$, $6, \mathrm{I}, 42$ 'he makes obeisance to the Fathers after pulling down the tuck'). It is therefore not surprising that it would be on the sacrificer's right side (KS. 31, 10: 12, 17). The men of the Vasistha family wore their hair braided and wound like a shell on the right side of the head ( $R V .7$, 33,1 ).

When the soma has been bought it is (VS. 4, 27) placed on the right thigh of Indra, i.e. of the sacrificer, who during the ceremonies is endowed with the nature and attributes of this god who is the mythical prototype: 'the gods placed the soma which they purchased on the right thigh of Indra' (cf. TS. I, 2, 7 g; 6, I, I I, I; $K S S$. 7, 8, 23 f.; $S B .3,3,3$, 10). No comment is furnished on the question as to why it should be the right knee; it was obviously self-evident.

The adhvaryu priest had to follow the cow with which the soma was bought in such a way that his right foot pressed six or seven foot-prints of the right foreleg of the animal $(\bar{A} p S S$. 10, 22, I I cf. TS. 6, 1, 8, 1; $K S .24,4: 92,16 ; M S .3,7,6: 82,17 ; S B .3,3,1,1)$; 'thereby he takes possession of her'. Omitting any comment on the numbers, which of course have a 'symbolical value' of their own, I would infer that the same act performed with the left foot in the left foot-prints would be far from yielding the result desired. A bride and bridegroom have to step onto a stone in order to acquire its firmness, but this act also should-no doubt for the same reason-be performed with their right feet (MGS. I, I0, I6).

If there are two co-operating officiants, the place to the right is in definite cases due to the one who ranks higher. When the adhvaryu priest 
and his assistant, the pratiprasthätar, are to deposit two cups on the fireplace, the former places his cup on the right, the latter on the left $(\hat{S B} B .4$, $2,1,15)$. Similarly, the adhvaryu has to set out while keeping to the southern side of the door, the pratiprasthätar while keeping to the north. The maitravaruna, the first assistant of the hotar, has his seat to the right of the latter, the brähmanacchamsin, the second of his assistants, to his left $(P B .5,1$, I4 $\mathrm{f}$.). There is indeed a sufficiency of places to show that the Vedic Indians, like other peoples, ${ }^{49}$ among whom modern Westerners, assigned a place or position to the right to those whom they considered to be higher or to whom they would show honour. When practising medicine one should have put down close by a pot of water and cause a brahman to sit down on one's right (TS. 6, 4, 9, 2 f.). Then one 'performs all medicine (which is an impure activity), and the remedy becomes effective'. From $S B$. I I, 5, 4, I4 it appears that some spiritual guides teaching a pupil who was to be initiated the sãvitri stanza used to recite this formula while the pupil was standing or sitting on their right side. The author, however, advises against this procedure (because it is not proper to give this place of honour to a pupil?), joining those authorities who have the teacher sit facing the east and the students sit in front of him facing the west. For the right side as the place of honour an interesting opinion of the "theologians' mentioned at VaikhSmS. 5, 8 may be quoted: 'The ascetic who is above dharma and non-dharma has caused the gods to sit down to his right, the Fathers to his non-right, sees the All in the Ätman . . . There is perhaps something to be said for the supposition that the right side became regarded as 'the place of honour' because, being superior to the person at his left from the point of view of offensive and protective possibilities, the man given that position may understand that he is trusted and reliable, or at least that he is dealt with as such.

According to the prevailing opinion of the ritualists there exists an opposition between the world of the gods and that of men in that various acts are, in the former, performed on the right, in the latter on the left side of a person's body. The conclusion that this distinction originated exclusively in a higher estimation of the right side may be too hasty and simplistic because not infrequently there can hardly be any doubt that the left side was in daily practice the normal part of the body to be subjected to a definite act. The sacrificer who undertakes the $d \bar{i} k s \bar{a}$ (consecration) has to cut his nails and comb his whiskers, first of the right hand and on the right side of his face and then to perform the same acts on the left side, because, the text $(S B .3,1,2,4$ f.) observes, in human practice the left side comes first, but with the gods the right side. Cf. also $S B$. 3 , $\mathrm{I}, 3,14$ ' $\mathrm{He}$ anoints the right eye first, for in human practice the left (eye is anointed) first'; $T S .6,1,1,6 ; M S .3,6,3: 62,7$. Now most people who are to cut their nails etc. will no doubt start on the left side because they use their right hands and the ritual direction to start on the right side may be due, not only to the greater strength of, and respect for, that limb, or to the customary left-to-right performance of various activities, but also to the conviction that in these things the divine world is a sort 
of inverted reflection of ours, an 'opposite world'. If two oxen are to be yoked, one begins in a similar way with the right one because 'so (it is done) with the gods, otherwise in human (practice)' $(S B .6,8,1,8 ; 7,2$, $2,6)$. 'The right yoke-horse is put to first, then the left yoke-horse, then the right side-horse: for thus it is (done) among the gods, otherwise in human (practice)' (SBB. 9, 4, 2, I I).

Although, in the Veda, the quarters of the universe are the regions of different gods (the east belongs to Agni: $S B .6,3,3,2$, the north to Rudra : $\left.14,2,2,3^{8}\right)$, this did not prevent the ritualists from assigning, for instance, the south to a variety of divine protectors (see p. 12). These correspondences are not always perfectly clear. We may make only guesses at the reason why the right side should belong to Mitra, the left to Varuna (TB. I, 7, 10, 1), whilst elsewhere $(T S .5,5,8,2)$ both gods are situated in the north, which in $A V P$. 19, 41, 2 is associated with Mitra alone, whereas in $S B$. 2, 5, 2, 10 Varuna is associated with that region. Most probably Mitra, the god of 'friendly' benevolence who puts things right, was regarded as more 'faustus' than his colleague, ${ }^{50}$ but perhaps his precedence in the usual compound Miträvaruña $\overline{(u)}$ may have contributed to associating him with the right side which is usually mentioned first. In this connection it is perhaps also worth recalling, on the one hand, that among many African peoples right is associated with light or white and left with dark (particularly red) colours (Wieschhoff, 1938: p. 214) and, on the other, that Mitra is frequently associated with the sun, light and the white colour, whereas Varuna is associated with what is dark and black (RV. I, I I5, 5; Gonda, I96o: p. 74).

Sometimes it is an association of ideas which prompted a definite ritual direction. Thus the portions of the flesh of the sacrificial horse are cut off while the dead body of this victim is lying north of the ahavaniya fire, because, it is emphasized, the horse is of the nature of the metre anustubh and the 'north is related to that metre' so that 'one thus places that (horse) in its own quarter' ( $S B$. 13, 2, 2, 19), an object worth pursuing because being in one's own place means being in harmony with the order of things. Accordingly it is from the left side of the horse that the (meat) portions are cut off, whereas the flesh of the other victims is cut off from the right side $(S B .13,3,1,2)$. In connection with this custom the author, however, furnishes us with a mythological motivation: the horse derives from the left eye of the creator-god Prajäpati. Hence also the direction in $S B$. 13, 5, 3, 8: of the blood of other victims portions are made on the south side, of that of the horse on the north side of the fire-place.

The brähmanas, which indeed are highly instructive with regard to the ancient Indian views of the connections between entities and phenomena, abound in more or less developed correlations and co-ordinations assumed to exist between these mutually and between these and the categories of time and space. Thus the rathantara säman (a particular type of chanted text) is identified with the earth and co-ordinated with the left side, the brhat säman, identified with heaven, with the right side $(S B .9,1,2,36 \mathrm{f}$.; $K a p S .31,20)$. While performing a definite ritual act, one should see that 
a black horse should stand on the left, a white on the right side (TS. 5, $7, \mathrm{I}, 2$; cf. $K S .22,8: 64,17)$; the white horse is said to be a manifestation of daytime, the black of night. It may be remembered that the right side is, in these instructions, the south.

There is a tendency directly or indirectly to associate those entities which from socio-religious points of view are comparatively speaking essential-for instance the earth $(\boldsymbol{S B} .9$, I, 2, 36)-with the right side. The reason may be sought in the association of the right with the idea of superiority and with such events or concepts as are understood to be good or favourable.

As far as I am able to see there are no Vedic passages which attest any special relations between the right and left side on the one hand and definite numbers on the other. ${ }^{51}$

Occasionally, a passage throws some light on differences of opinion with regard to the interpretation of ritual acts. Thus, the author of $S B .3$, $7,2,5 \mathrm{f}$, whilst expatiating upon the question as to how definite stakes are to be placed most effectively, maintains that the stake on the southern (right) flank should be set up last of all, in order to achieve an inclination to the north, which is desired and auspicious, without however suppressing the opposite view of those who place the one on the northern (left) flank last in order to attain completion towards that side. As is well known, similar complications or 'conflicting situations' present themselves also in other countries: the Toradjas consider the grunt of a boar on the left to be a favourable omen because it forebodes ill for the enemies who of course are associated with the unfavourable half of the universe (Kruyt, I94I: p. 348). Moreover, the tendency does not seem to have been alien to various peoples to attach, in considering omina etc., more importance to the direction of a movement than to its starting-point. ${ }^{52}$ Two or three different procedures may be feasible and even recommended, provided a series of ritual acts terminates in a definite position on the left: at $S B$. 3 , $5,4,6 \mathrm{f}$. the order in which to draw the outlines of the holes over which the soma is to be ground may be, either the right side in front, the left behind, the right behind, the left in front, or the left behind, the right in front, the right behind, the left in front, or also SE., SW., NW., NE., "but let him in any case mark off last of all the one which is on the left of those in front'.

If in a definite ritual situation one finds oneself between two alternative difficulties one may get out of them by doing, in a way, one thing as well as the other. Thus TS. $3,4,10,3 \mathrm{f}$. (compare $M S$. I, 5, 13:82, $5 \mathrm{ff}$.) prescribes that if a man were to offer with the chariot yoked, that would be as one offers an oblation on a place one has left; if he were to offer without the chariot being yoked, that would be as when one offers an oblation at rest. Therefore one should offer whilst one animal is yoked and the other left unyoked. It is, however, worth noticing that it is the right animal which is not only mentioned first, but is also to be yoked.

What is very rare is that an author does not offer an opinion in this matter or leaves the decision to the officiants: $S B$. $13,8,2,5$ 'he (the 
officiant) then yokes (the team) to the plough on the south side-some say on the north side-he may do as he chooses'. Āpastamba's Srautasütra 12, 10, 14 and 12, 13, 7 is interesting in that it enjoins those who offer the oblations called upämsugraha and antaryämagraha, which are each other's opposite (Caland-Henry, 1906: pp. $155 \mathrm{ff}$; $160 \mathrm{ff}$.), to make a definite movement to the south of the hotar and to his north respectively or, in both cases, 'on which way the hotar allows him to pass'.

NOTES

1. For some supplementary material drawn from manuals used by the followers of Vedic schools in medieval and modern times, see Kane, r953: pp. $486 \mathrm{ff}$.

2. In this article, no attempt will be made to discuss the question of handedness physiologically or psychologically.

3. In connection with Caland's observations on the pradaksina it is worth recalling that by the Toradjas the right side, actions performed on that side, circumambulations etc., the flight of lucky birds in that direction are considered 'to secure life or generate life power', the left side meaning death and destruction.

4. At $R V$. I0, 22, 14 the circumambulation from left to right can hardly with Geldner (1951: III, p. 159) be executed with regard to Susna, who is to be destroyed, but is rather to protect the earth (compare the commentator Sãyana).

5. It is, however, worth observing that, for instance, the frequent ritual circumambulations of the peoples of Celebes and the 'theory' underlying them, as briefly described by Kruyt ( $194 \mathrm{I}$ : pp. $353 \mathrm{ff}$.), are in several respects similar to the circumambulations of the Indians. A movement to the right 'brings, or leads to, life', a movement to the left 'leads towards death'. For circumambulations in ancient Greece: Cuillandre, 1944: pp. 28 I ff.

6. Authors of Vedic as well as post-Vedic texts often add the adjective for 'right' in describing manual acts (see, e.g., Bāna, Harșacarita 3: an ascetic using his rosary). Various ritual acts should be performed while standing to the right side of a sacred object: see, e.g., the Viṣnuite Käsyapa-Samhitā, ch. 68.

7. For Indonesian references to ominous birds and their cries from the right or from the left, see Kruyt, 1941 : pp. $346 \mathrm{ff}$.

8. In his discussion of the Celebes circumambulations Kruyt, loc. cit., does not mention the sun.

9. Compare also $S B .9,1,2,36$.

Io. According to Werner (1904: pp. $112-116$ ), the right hand is, in the Bantu-speaking parts of Africa, sometimes called the 'strong hand'.

II. Onians, I954: p. 97 (and I98) goes so far as to suggest that the sanctity of the right hand given with a promise is explicable from its being 'the executive member representing and pledging the life soul'.

12. Eitrem, 1915: p. 30: the natural inclination to turn to the right agrees with the course of the sun.

13. See also TS. 5, 2, 5, 4. For other texts, see Caland, 1898: p. 10, n. 2.

14. Compare, however, also such places as VS. 37, 12 'Rich in sons from the south in Indra's overlordship give me (the Earth is addressed) offspring'.

15. See further on, p. 15 .

I6. See further on, p. I4.

17. Not quite convincingly, it is true, because of the word pari.

18. For the left hand as the 'bad' and unlucky one in Africa, see Wieschhoff, 1938: pp. $206 \mathrm{ff} ., 211 \mathrm{ff}$.

19. For the combination of these two qualities, see also TS. I, 5, 8, 5; 1, 7, 6, 5 and especially $5,6,2,6:$ "This oblation is food in very presence; in that he "places" this oblation, verily he wins food . . . He says "Thou are brahmavarcasa; for brahmavarcasa (I offer) thee". Possessed of brilliant energy and of brahmavarcasa does he become for whom these are "placed" and who knows it thus'.

20. See further on, p. 12 . 
21. In view of the fact that most people are right-handed, these semantic relations are very well intelligible without any reference to religion or views of life.

22. For African parallels, see Wieschhoff, 1938: pp. $203 \mathrm{ff}$.

23. It would be interesting to know if the curious fact that in the Madura district the Chakkiliyan men belong to the right-hand faction while their wives are most energetic supporters of the left (Thurston, 1906: p. 47), has anything to do with this ancient and widespread belief.

24. See Oertel, 1906: p. 188 who refers to Vätsyãyana's Handbook of erotics, p. $13^{8}$ of the text, p. 101 of the commentary.

25. Compare also $S B .2,5,2,17 ; 7,5,1,36$.

26. The above position of Varuna seems at first sight to contradict the statement made, e.g., in $S B .8,6,1,7$, viz. that Varuna is the protector of the west. It should, however, be borne in mind that the Varupapraghäsa, the second of the Seasonal sacrifices, which is to be performed at the beginning of the rainy season, is a typically Varunic rite instituted according to $S B .2,5,2,4$ to deliver one's offspring from the god's noose. Contrary to expectation, only one of the two oblations, viz. that in the northern fire, is offered to Varuna, the southern one to the Maruts, the gods of wind and rain, who have a share in this fertility and agricultural ritual. This is $(S B .2,5$, 2, I0) done for the sake of diversity and to avoid repetition; moreover, it was from the south that the Maruts, like other inimical powers, intended to slay the creatures, so that they are not to be propitiated with the southern oblation. It was, on the other hand, the task of the pratiprasthätar, the assistant of the adhvaryu, to imitate on the south-side what the latter performed on the north-side.

27. In definite regions of Africa, the man lies on his right side and the woman on her left. 'This would seem to imply that the man's left hand alone is free for sexual play' (Needham, 1967: p. 429).

28. 'The logical connection of the two sentences is obscure' (Oertel, r896: p. 234).

29. Cf. also the physician Caraka (second century A.D.?) 4, 2, $28 \mathrm{f}$. The same belief seems to have obtained in the case of supernatural births: $M b h .1,60,3^{\circ} \mathrm{cr}$. ed. the god Dharma comes into existence out of the right breast of Brahmā.

30. Otherwise, Eggeling, 1897: IV, p. 81, n. 3, who regards the clause 'on the left in the case of a woman' as rather abrupt and hardly logical. If other bricks are compared with the woman, it must be those which are placed on the left (i.e. north) side.

31. Similarly, in classical texts (Kālidāsa, Raghuvamúa, 3, I4; Bāṇa, Harșacarita, 142). A flame which goes to the left portends evil (Mahabhärata 6, 3, 38). In the case of a man 'throbbing of the left eye causes anguish' (Mrcchakatika 6, 10), but with a woman this omen is reversed (Kālidāsa, Sakuntalä $5,11+$ ). The same belief is not foreign to tribal religion: if, for instance, the right leg of a cock throttled for augural purposes is down and the left up the husband will die first; if the right is up and the left down, the wife (Mills, I922: p. 151).

32. According to, for example, the much later Kälika-Puräna 57,42 one should not touch one's rosary with one's left hand.

33. Caland, 1900: p. I 46 erroneously translates: 'right'.

34. I leave the opposition between the gods or men (in the north) and the Fathers (in the south: $S B$. 12, 7, 3, 7; 12,8, 3,6) out of consideration.

35. Many Africans observe the rule that in no case may a woman touch her husband's face with the left hand (Wieschhoff, 1938: p. 207).

36. 'A la main droite vont les honneurs, les désignations flatteuses, les prérogatives: elle agit, elle ordonne, elle prend. Au contraire, la main gauche est méprisée et réduite au rôle d'humble auxiliaire: elle ne peut rien par elle-même; elle assiste, elle seconde, elle tient' (Hertz, 1909: p. 553).

37. That the right side of a thing-at $A V .4,14,7$ of a victim-belongs to the southern quarter of the sky is as self-evident as the attribution of the left side to the north (ibid. 8). For the relations between lateral symbolism and the quarters of the universe in general, see Cuillandre, 1944: pp. $1 \mathrm{ff}$.

38. Cf., e.g., also TS. $2,6,4,3$.

39. A ritual explanation is, for instance, also given of the fact that plants and herbs ripen first in the south (or, at the southern side) $K S .23,8: 84,10$. 
40. One might also compare places such as $\mathcal{S B} .8,2,4,17 \mathrm{f}$. For right and left denoting orientation, see also Wieschhoff, 1938: p. 215.

41. In Africa, one should 'not use the left hand for good acts, which in accordance with custom are performed with the right, such as eating, giving alms, offering and receiving food or drink or other things' (Wieschhoff, 1938: p. 206). See also Needham, $1967:$ p. 426.

42. Describing the ceremonious offering of a box of betle Tonquin, Voyages and Discoveries, p. 52, quoted by Penzer, 1952: p. 273, relates that 'the attendant that brings it, holds it to the left hand of the stranger, who therewith taking off the cover, takes with his right hand the nuts out of the box. 'T were an affront to take them or give or receive anything with the left hand, which is confined all over India to the viler uses'.

43. Cf. e.g., the Tantric Mahänirvänatantra, $6,4^{8 .}$

44. Compare also Pränägnihotra-Upaniṣad, 2 (translated by Deussen, ${ }^{4} 1963:$ p. 614).

45. In Africa also, 'repulsion from the use of the left-hand is especially strong in respect to food' (Wieschhoff, 1938: p. 206).

46. See, e.g., also KapS. 31, 12: 160, 20; 31, 13: 161, 18.

47. With African peoples certain sacred cows are, like ordinary cows, milked from the right side (Needham, 1967: p. 429).

48. For which see Caland, $1898:$ pp. $8 \mathrm{f}$.

49. Cf., e.g., Acta Apost. 2, 25; 33; 34; Suetonius, Nero, 13.

5o. It might be observed that with African peoples the good right hand indicates friendship, the left animosity (Wieschhoff, 1938: p. 207).

51. From various customs and ceremonies it appears that in at least some Indian communities the left is associated with the number nine and the right with the number ten: ten objects are, for instance, to be put in the latter, nine in the former (Mills, 1922: pp. 47; 49; 128).

52. I refer to Jevons, pp. $22 \mathrm{ff}$.

\section{REFERENCES}

Atkins, S. D. (1941). Püssan in the Rig-Veda. Princeton: private edition.

Caland, W. (1898). Een Indogermaansch lustratie-gebruik. Amsterdam: Royal Dutch Academy, Verslagen en Mededeelingen Letterkunde, 4, II.

Caland, W. (1900). Altindisches Zauberritual. Amsterdam: Royal Dutch Academy, Verhandelingen Letterkunde, III, 2.

Caland, W., and Henry, V. (Igo6). L'Agniștoma. Paris: E. Leroux.

Cuillandre, J. (1944). La droite et la gauche dans les poimes homériques. Paris.

Deussen, P. (41963). Sechzig Upanishad's des Veda. Darmstadt: Wissenschaftliche Buchgesellschaft.

Eggeling, J. (1882-1900). The Satapatha-Brähmana translated. Sacred Books of the East. Oxford: Clarendon Press.

Eitrem, S. (1915). 'Opferritus und Voropfer der Griechen und Römer'. Skrifter Videnskapsselskapet i Kristiania I914, II, I.

Geldner, K. F. (195I). Der Rig-Veda übersetzt, 3 volumes. Cambridge Mass.: Harvard University Press.

Gonda, J. (1955). 'The etymologies in the ancient Indian brāhmaṇas'. Lingua 5, p. 61 ff. Amsterdam: North-Holland Publ. Comp.

Gonda, J. (1960). Die Religionen Indiens, I. Stuttgart: Kohlhammer Verlag.

Gonda, J. (I g66). Ancient Indian kingship from the religious point of view. Leyden: E. J. Brill.

Gonda, J. (1970). Visnuism and Sivaism. Jordan Lectures 1969. University of London: Athlone Press.

Hertz, R. (I909). 'La prééminence de la main droite. Etude sur la polarité religieuse'. Revue philosophique 68, p. 553 ff. Paris; also (1928) in Mélanges de sociologie religieuse et folklore, Paris, and in an English translation by R. and C. Needham. 1960. Death and the Right Hand. London, Cohen and West (with a bibliography on pp. $172 \mathrm{ff}$.).

Hillebrandt, A. (I897). 'Ritualliteratur. Vedische Opfer und Zauber'. Grundriss der indoarischen Philologie und Altertumskunde, III, 2. Strassburg: K. J. Trübner. 
JAOS. Journal of the American Oriental Society. New Haven, Conn.: Yale Univ. Press.

Jevons, F. B. 'Indoeuropean modes of orientation'. The Classical Review, 10.

Jokes, G. (196r). Dictionary of Mythology, folklore and symbols. New York.

Jolly, J. (Igor), Medicin. Grundriss der indo-arischen Philologie und Altertumskunde, III, 10. Strassburg: K. J. Trübner.

Kane, P. V. (1953). History of Dharmasāstra, IV. Poona: Bhandarkar Oriental Research Institute.

Keith, A. B. (Igo8). Sänkhäyana Aranyaka. London: The Royal Asiatic Society.

Kruyt, Alb. C. (194I). 'Rechts en links bij de bewoners van Midden-Celebes'. Bijdragen tot de Taal-, Land-en Volkenkunde van Nederlandsch-Indië, 100, p. 339 ff. The Hague.

Meyer, J. J. (1937). Trilogie altindischer Mächte und Feste der Vegetation, 3 vol. ZürichLeipzig: M. Niehans Verlag.

Mills, J. P. (I922). The Lhota Nagas. London: Macmillan and Co.

Needham, R. (1967). 'Right and left in Nyoro symbolic classification'. Africa, 1937.

Oertel, H. (1896). 'Jaiminiya-Upanișad-Brāhmana', JAOS I6.

Oertel, H. (1906). 'Contributions to the history of the Brahhmana literature', JAOS 26.

Onians, R. B. (1954). The origins of European thought. Cambridge, University Press.

Penzer, N. M. (1952). Poison-damsels. London, Sawyer Ltd.

Thurston, E. Th. (1906). Ethnic notes in Southern India. Madras, Government Press.

Weinreich, O. (I921). Review of Eitrem, Opferritus (see above). Göttingische Gelehrte Anzeigen, 192 I, p. $133 \mathrm{ff}$. Göttingen.

Werner, A. (1904). 'Right and left hand in Bantu'. Journal of the African society. London.

Wieschhoff, Heinz A. ( $\left.193^{8}\right)$. 'Concepts of right and left in African cultures'. Journal of the American Oriental Society, 58, p. $202 \mathrm{ff}$. New Haven, Conn.

Wile, Ira S. (1934). Handedness. Right and left. Boston Mass. 
Abrreviations (titles of Sanskrit texts)

AiB. Aitareyabrāhmaṇa

ĀpDhS. Āpastambadharmasūtra

ĀpSS. A Apastambaśrautasūtra

AV. Atharvavedasamhitā (Śaunakiya)

AVP. Atharvavedasamhitã (Paipallāda)

AVPar. Atharvavedapariśișța

BhārParS. Bhāradvājapariśișțasūtra

BŚS. Baudhāyanaśrautasūtra

GB. Gopathabrāhmaña

JUB. Jaiminiya-upaniṣadbrāhmana

KapS. Kapișthalakaṭhasaṃhitā

KS. Kāṭhakasamhitā

KŚS. Kātyāyanaśrautasūtra

Mbh. Mahābhārata

MGS. Mānavagrhyasūtra

MS. Maitrāyaṇisamụitā

MŚS. Mānavaśrautasūtra

PB. Pañcavimiśabrāhmaṇa

RV. R Ruedasamhitā

RVKh. Rgveda-khila

ṠA. SSänkhãyana-āraṇyaka

SB. Satapathabrāhmana

SGS. Śānkhāyanagṛhyasūtra

ŚSS. Śānkhäyanaśrautasūtra

TB. Taittiriyabrāhmaṇa

TS. Taittirìyasamhitã

VaikhSmS. Vaikhānasasmārtasūtra

VS. Vājasaneyisaṃhitā 